\title{
RODITELJI I DJEČJE GLAZBENE AKTIVNOSTI U OBITELJSKOM DOMU
}

\author{
Marijo Krnić1, Josipa Kodžoman-Radan ${ }^{2}$ \\ ${ }^{1}$ Odsjek za učiteljski studij, Filozofski fakultet, \\ Sveučilište u Splitu, Hrvatska \\ mkrnic@ffst.hr \\ 2 Split, Hrvatska \\ josipa.radan@gmail.com
}

Primljeno: 18. 9. 2015.

\begin{abstract}
U ovom radu predstavljeni su rezultati istraživanja utjecaja zaposlenosti $i$ stečene stručne spreme roditelja na količinu vremena koju oni provode s djecom u glazbenim i ostalim (neglazbenim) aktivnostima u obiteljskom domu. Istraživanje je provedeno u lipnju 2015. godine u četirima splitskim vrtićima, na uzorku od 160 roditelja 80-ero djece predškolskog uzrasta. Rezultati ukazuju na to da ne postoji statistički značajan utjecaj zaposlenosti $i$ stručne spreme na količinu vremena koju roditelji provode s djecom u glazbenim i ostalim (neglazbenim) aktivnostima. Utjecaj zaposlenosti roditelja statistički je značajan pri razini signifikantnosti od $10 \%(p=0,053<10 \%)$ i to na način da obitelji u kojima je samo jedan roditelj zaposlen provode više vremena $s$ djecom u glazbenim aktivnostima nego obitelji u kojima su oba roditelja zaposlena.
\end{abstract}

Ključne riječi: glazbene sposobnosti, zaposlenost, stručna sprema, glazbeni odgoj, djeca predškolskog uzrasta

\section{Uvod*}

Glazbeni odgoj važan je dio sveukupnog estetskog i umjetničkog odgoja, a utječe na cjelokupni afektivni, socijalni, kognitivni i psihomotorički razvoj djeteta (Denac, 2004; Marić i Goran, 2013). Glazbeni

* Rad pod naslovom Glazba za dijete i roditelji završna je radnja obranjena 2015. godine na Filozofskom fakultetu Sveučilišta u Splitu, na Odsjeku za predškolski odgoj, pod mentorstvom mr. sc. Marija Krnića. 
razvoj djeteta dio je, dakle, njegova općeg razvoja, a predškolska dob pravo je vrijeme za razvoj djetetovih glazbenih sposobnosti (Denac, 2008; Gordon, 1988; Panagiotakou i Pange, 2010). Prema Manasteriotti (1982), elementi (glazbenog) estetskog odgoja u radu s djecom su: buđenje i razvijanje osjećaja i smisla za lijepo u glazbi, osposobljavanje za zapažanje estetskih svojstava glazbe, pozicioniranje glazbe kao izvora djetetovih estetskih doživljaja, postavljanje osnova glazbenog ukusa djece, razvijanje stvaralačke snage djeteta u smislu estetski oblikovanog istraživanja u tim područjima, usvajanje elementarnih znanja i vještina te ovladavanje određenim navikama estetskog karaktera.

Dječji razvoj ovisan je o naslijeđu, okolini i njegovim vlastitim aktivnostima. Isti čimbenici utječu i na razvoj glazbenih sposobnosti. Manasteriotti (1982) navodi da kvaliteta glazbenih sposobnosti ovisi o urođenim dispozicijama, stupnju razvijenosti tih predispozicija, socijalnoj sredini djeteta te pedagoškom utjecaju na dijete. U čimbenike koji pridonose uravnoteženom razvoju djeteta pomoću glazbe Šulentić Begić (2012) ubraja: poduža razdoblja angažmana s glazbom kroz praksu i istraživanja, podršku od strane roditelja i drugih odraslih, odnos s odgajateljem okarakteriziran toplinom i uzajamnom naklonošću te rana iskustva s glazbom koja razvijaju senzitivna i afektivna iskustva.

Nemoguće je utvrditi točno kada se kod pojedinog djeteta razvija pojedina glazbena sposobnost. Isto tako, ovisno o okolini, djeca iste starosti mogu biti na različitim razvojnim stupnjevima glazbenih sposobnosti. Manasteriotti (1981) drži da se sva djeca rađaju s nekim glazbenim sklonostima koje se u prvoj godini u povoljnim uvjetima mogu razviti u elementarne sposobnosti, a u nepovoljnim prilikama većinom će ostati nerazvijene. Važnost utjecaja činitelja iz okruženja na razvoj dječjih glazbenih sposobnosti prepoznaje i Dobrota (2007), naglašavajući važnost da dijete odrasta u glazbenom poticajnom ozračju. Miočić (2012) također ističe značajan utjecaj okružja, držeći kako u stimulativnom okruženju dijete razvija svoje glazbene sposobnosti koje obuhvaćaju shvaćanje i pamćenje melodije, percepciju ritma, shvaćanje tonaliteta, utvrđivanje intervala, uočavanje estetskog značenja glazbe i apsolutnog sluha. Poticajno okruženje, između ostalog, podrazumijeva i uvažavanje aktivne istraživačke i otkrivačke prirode učenja djece, kao i činjenice da su djeca socijalna bića koja od najranije dobi stupaju u svrhovite socijalne interakcije s okolinom (Slunjski, 2012). MirkovićRadoš (1983) glazbene sposobnosti definira kao niz stečenih međusob- 
no povezanih ponašanja koja su nastala kroz proces interakcije pojedinaca s glazbenim poticajima tijekom života. Upravo zato, važno je djeci već od prve godine života priređivati susrete s glazbom (Levinowitz, 1998; Marić i Goran, 2013).

Naglašavajući važnost odgojnog utjecaja roditelja na djecu, Jurak ističe kako su djeca »dvostruki baštinici: svijeta koji nasljeđuju tjelesnim rađanjem i svijeta koji u njih ulazi roditeljskim odgojem « (Jurak, 2002 , 4). Važnost uloge roditelja u svestranom razvoju djeteta ističe i Ljubetić (2007), držeći ih prvim i najznačajnijim odgajateljima svoga djeteta, prvim modelima identifikacije i imitacije, prvim uzorima za učenje te mostom za uspostavljanje socijalnih kontakata sa širim okruženjem. Ulogu roditelja i obitelji općenito u glazbenom razvoju djeteta naglašavaju Dobrota i Ćurković (2006), ističući kao kritični period za glazbeni razvoj razdoblje od treće do šeste godine djetetova života pa se stoga trebaju planirati glazbene aktivnosti koje bi potakle takav razvoj. U prilog ovoj tezi ide i konstatacija Jože Požgaja (1988) da djeca iz glazbeno pasivnih obitelji pri ulasku u školu najčešće pokazuju manje razvijene glazbene sposobnosti i manju zainteresiranost za glazbene aktivnosti.

\section{Cilj i zadaće istraživanja}

Istraživanjem se htjelo utvrditi koliko vremena roditelji provode s djecom u glazbenim i ostalim (neglazbenim) aktivnostima. Svrha istraživanja je proširiti nalaze na području razvoja glazbenih sposobnosti te na taj način doprinijeti podizanju kvalitete $u$ radu na razvoju istih.

U skladu s navedenim ciljem istraživanja, formulirane su sljedeće zadaće istraživanja:

- utvrditi odnos zaposlenosti roditelja predškolske djece i dnevnog prosječnog vremena provedenog u glazbenim aktivnostima $\mathrm{s}$ djecom u roditeljskom domu;

- utvrditi odnos zaposlenosti roditelja predškolske djece i dnevnog prosječnog vremena provedenog u ostalim (neglazbenim) aktivnostima s djecom u roditeljskom domu;

- utvrditi odnos stručne spreme roditelja predškolske djece i dnevnog prosječnog vremena provedenog u glazbenim aktivnostima $\mathrm{s}$ djecom u roditeljskom domu; 
- utvrditi odnos stručne spreme roditelja predškolske djece i dnevnog prosječnog vremena provedenog u ostalim (neglazbenim) aktivnostima s djecom u roditeljskom domu.

U skladu s formuliranim ciljem istraživanja postavljene su sljedeće hipoteze:

H1: Postoji statistički značajan utjecaj zaposlenosti roditelja predškolske djece na dnevno prosječno vrijeme provedeno u glazbenim aktivnostima s djecom u roditeljskom domu.

H2: Postoji statistički značajan utjecaj zaposlenosti roditelja predškolske djece na dnevno prosječno vrijeme provedeno u ostalim (neglazbenim) aktivnostima s djecom u roditeljskom domu.

H3: Ne postoji statistički značajan utjecaj stručne spreme roditelja predškolske djece na dnevno prosječno vrijeme provedeno u glazbenim aktivnostima s djecom u roditeljskom domu.

H4: Ne postoji statistički značajan utjecaj stručne spreme roditelja predškolske djece na dnevno prosječno vrijeme provedeno $u$ ostalim (neglazbenim) aktivnostima s djecom u roditeljskom domu.

\subsection{Metodologija istraživanja}

\subsubsection{Uzorak}

U istraživanju je sudjelovalo ukupno 160 očeva i majki 80 -ero djece predškolskog uzrasta, koja pohađaju predškolske ustanove na području grada Splita. Odabrani uzorak je slučajan.

\subsubsection{Instrument i postupak ispitivanja}

Za potrebe ovog istraživanja konstruiran je poseban upitnik kojim smo prikupljali sljedeće podatke: zaposlenost očeva i majki, stečeni stupanj stručne spreme očeva i majki, prosječno dnevno vrijeme provedeno u glazbenim aktivnostima s djecom u roditeljskom domu te prosječno dnevno vrijeme provedeno u ostalim (neglazbenim) aktivnostima s djecom u roditeljskom domu. Istraživanje je provedeno u lipnju 2015. godine u četirima splitskim vrtićima: Adriana, Mala sirena, Mirta i Zvončić. 


\subsection{Analiza rezultata $i$ interpretacija}

U Tablici 1 prikazana je zaposlenost majki iz koje je vidljivo da je $71,25 \%$ majki zaposleno, a $28,75 \%$ nezaposleno.

Tablica 1. Zaposlenost majki

\begin{tabular}{|l|c|c|}
\hline Zaposlena & N & \% \\
\hline $\mathrm{Da}$ & 57 & 71,25 \\
\hline $\mathrm{Ne}$ & 23 & 28,75 \\
\hline Ukupno & 80 & 100 \\
\hline
\end{tabular}

U Tablici 2 prikazana je zaposlenost očeva. Zaposleno je 96,25\% očeva, a nezaposlenih je 3,75\%.

Tablica 2. Zaposlenost očeva

\begin{tabular}{|l|c|c|}
\hline Zaposlen & N & \% \\
\hline $\mathrm{Da}$ & 77 & 96,25 \\
\hline $\mathrm{Ne}$ & 3 & 3,75 \\
\hline Ukupno & 80 & 100 \\
\hline
\end{tabular}

U Tablici 3 prikazana je zaposlenost roditelja u jednoj obitelji. U $67,5 \%$ anketiranih obitelji oba su roditelja zaposlena, a u 32,5\% obitelji samo je jedan roditelj zaposlen. Nije bio niti jedan slučaj gdje su oba roditelja nezaposlena.

Tablica 3. Zaposlenost oba roditelja

\begin{tabular}{|l|c|c|}
\hline Zaposlen/a & N & \% \\
\hline Oba roditelja zaposlena & 54 & 67,5 \\
\hline Samo jedan roditelj zaposlen & 26 & 32,5 \\
\hline Ukupno & 80 & 100 \\
\hline
\end{tabular}


Tablica 4. Stupanj stručne spreme majki

\begin{tabular}{|l|r|c|}
\hline Stupanj stručne spreme & N & $\mathbf{~}$ \\
\hline Niža stručna sprema & 2 & 2,5 \\
\hline Kvalificiran (III. stupanj) & 0 & 0 \\
\hline Srednja stručna sprema & 26 & 32,5 \\
\hline Visokokvalificiran (V. stupanj) & 3 & 3,75 \\
\hline Viša stručna sprema & 22 & 27,5 \\
\hline Visoka stručna sprema & 24 & 30 \\
\hline Visoka stručna sprema s magisterijem i/ili doktoratom & 3 & 3,75 \\
\hline Ukupno & 80 & 100,0 \\
\hline
\end{tabular}

Osim zaposlenosti roditelja, istraživanjem smo htjeli utvrditi utječe li na provođenje vremena s djecom (u glazbenim i ostalim aktivnostima) i stupanj stečene stručne spreme roditelja. Iz podataka u Tablici 4 razvidno je da je najviše majki sa srednjom stručnom spremom, potom s visokom i višom stručnom spremom, 3,75\% majki je visokokvalificirano ili ima visoku stručnu spremu s magisterijem ili doktoratom, a najmanje ih je $(2,5 \%)$ s nižom stručnom spremom.

Tablica 5. Stupanj stručne spreme očeva

\begin{tabular}{|l|r|c|}
\hline Stupanj stručne spreme & N & \% \\
\hline Niža stručna sprema & 2 & 2,5 \\
\hline Kvalificiran (III. stupanj) & 1 & 1,25 \\
\hline Srednja stručna sprema & 31 & 38,75 \\
\hline Visokokvalificiran (V. stupanj) & 1 & 1,25 \\
\hline Viša stručna sprema & 15 & 18,75 \\
\hline Visoka stručna sprema & 25 & 31,25 \\
\hline Visoka stručna sprema s magisterijem i/ili doktoratom & 5 & 6,25 \\
\hline Ukupno & 80 & 100 \\
\hline
\end{tabular}

Iz podataka u Tablici 5 iščitavamo kako najviše očeva, njih 38,75\%, ima srednju stručnu spremu, $31,25 \%$ visoku stručnu spremu, $18,75 \%$ steklo je višu stručnu spremu, a najmanje ih je kvalificirano (III. stupanj) i visokokvalificirano (V. stupanj), po 1,25\%. 
Tablica 6. Prosječno dnevno zajedničko provođenje vremena s djecom u glazbenim aktivnostima

\begin{tabular}{|l|c|c|}
\hline $\begin{array}{c}\text { Vrijeme provedeno u glazbenim } \\
\text { aktivnostima }\end{array}$ & N & \% \\
\hline Manje od pola sata & 30 & 37,5 \\
\hline $1 \mathrm{~h}$ & 21 & 26,25 \\
\hline $1 \mathrm{~h}-2 \mathrm{~h}$ & 19 & 23,75 \\
\hline $2 \mathrm{~h}-4 \mathrm{~h}$ & 8 & 10,0 \\
\hline Više od 4 sata & 2 & 2,5 \\
\hline Ukupno & 80 & 100,0 \\
\hline
\end{tabular}

Iz podataka u Tablici 6 je razvidno da 2,5\% roditelja provodi više od 4 sata s djecom u nekoj glazbenoj aktivnosti, dok 37,5\% roditelja provodi manje od pola sata. Iz podataka u Tablici 7 iščitavamo da $83,75 \%$ roditelja provodi najmanje jedan (1) sat u neglazbenim aktivnostima s djecom.

Tablica 7. Prosječno dnevno zajedničko provođenje vremena s djecom u ostalim (neglazbenim) aktivnostima

\begin{tabular}{|l|c|c|}
\hline \multicolumn{1}{|c|}{$\begin{array}{c}\text { Vrijeme provedeno u ostalim } \\
\text { (neglazbenim) aktivnostima }\end{array}$} & $\mathbf{N}$ & $\mathbf{\%}$ \\
\hline Manje od pola sata & 3 & 3,75 \\
\hline $1 \mathrm{~h}$ & 10 & 12,5 \\
\hline $1 \mathrm{~h}-2 \mathrm{~h}$ & 19 & 23,75 \\
\hline 2h-4h & 30 & 37,5 \\
\hline Više od 4 sata & 18 & 22,5 \\
\hline Ukupno & 80 & 100,0 \\
\hline
\end{tabular}

Roditelji su podijeljeni u dvije skupine (tablice 8 i 9): skupina $u$ kojoj su oba roditelja djeteta zaposlena i skupina u kojoj je samo jedan roditelj zaposlen (nije postojao niti jedan slučaj da su oba roditelja nezaposlena). 
Tablica 8. Odnos zaposlenosti i prosječnog dnevnog vremena provedenog s djetetom u glazbenim aktivnostima

\begin{tabular}{|c|c|c|c|c|}
\hline \multirow{2}{*}{\multicolumn{2}{|c|}{$\begin{array}{l}\text { Prosječno dnevno vrijeme } \\
\text { provedeno s djetetom u } \\
\text { glazbenim aktivnostima }\end{array}$}} & \multicolumn{3}{|c|}{ Zaposlenost } \\
\hline & & \multirow{2}{*}{$\begin{array}{c}\text { Oba roditelja } \\
23 \\
\end{array}$} & \multirow{2}{*}{$\begin{array}{c}\text { Jedan roditelj } \\
7 \\
\end{array}$} & \multirow{2}{*}{$\begin{array}{c}\text { Ukupno } \\
30\end{array}$} \\
\hline Moni o do noto & $\mathrm{N}$ & & & \\
\hline Manje od pola sata & $\%$ & 42,6 & 26,9 & 37,5 \\
\hline \multirow{2}{*}{$1 \mathrm{~h}$} & $\mathrm{~N}$ & 15 & 6 & 21 \\
\hline & $\%$ & 27,8 & 23,1 & 26,3 \\
\hline \multirow{2}{*}{$1 \mathrm{~h}-2 \mathrm{~h}$} & $\mathrm{~N}$ & 12 & 7 & 19 \\
\hline & $\%$ & 22,2 & 26,9 & 23,8 \\
\hline \multirow{2}{*}{$2 h-4 h$} & $\mathrm{~N}$ & 3 & 5 & 8 \\
\hline & $\%$ & 5,6 & 19,2 & 10,0 \\
\hline \multirow{2}{*}{ Više od 4 sata } & $\mathrm{N}$ & 1 & 1 & 2 \\
\hline & $\%$ & 1,9 & 3,8 & 2,5 \\
\hline \multirow{2}{*}{ Ukupno } & $\mathrm{N}$ & 54 & 26 & 80 \\
\hline & $\%$ & 100,0 & 100,0 & 100,0 \\
\hline
\end{tabular}

Tablica 9. Odnos zaposlenosti i prosječnog dnevnog vremena provedenog s djetetom u ostalim (neglazbenim) aktivnostima

\begin{tabular}{|l|c|c|c|c|}
\hline \multirow{2}{*}{$\begin{array}{c}\text { Prosječno dnevno vrijeme } \\
\text { provedeno s djetetom u ostalim } \\
\text { (neglazbenim) aktivnostima }\end{array}$} & \multicolumn{3}{|c|}{ Zaposlenost } \\
\cline { 2 - 5 } & Oba roditelja & Jedan roditelj & \multirow{2}{*}{ Ukupno } \\
\hline \multirow{2}{*}{ Manje od pola sata } & $\mathrm{N}$ & 2 & 1 & 3 \\
\cline { 2 - 5 } & $\%$ & 3,7 & 3,8 & 3,8 \\
\hline \multirow{2}{*}{$1 \mathrm{~h}$} & $\mathrm{~N}$ & 6 & 4 & 10 \\
\cline { 2 - 5 } & $\%$ & 11,1 & 15,4 & 12,5 \\
\hline \multirow{2}{*}{$1 \mathrm{~h}-2 \mathrm{~h}$} & $\mathrm{~N}$ & 16 & 3 & 19 \\
\cline { 2 - 5 } & $\%$ & 29,6 & 11,5 & 23,8 \\
\hline \multirow{2}{*}{$2 \mathrm{~h}-4 \mathrm{~h}$} & $\mathrm{~N}$ & 21 & 9 & 30 \\
\hline \multirow{2}{*}{ Više od 4 sata } & $\%$ & 38,9 & 34,6 & 37,5 \\
\hline \multirow{2}{*}{ Ukupno } & $\mathrm{N}$ & 9 & 9 & 18 \\
\cline { 2 - 5 } & $\%$ & 16,7 & 34,6 & 22,5 \\
\hline
\end{tabular}


Proveden je Mann-Whitney test za usporedbu ordinalne varijable u dvije nezavisne skupine. Iz ispitanog uzorka ne se može dokazati da postoji statistički značajan utjecaj zaposlenosti roditelja na vrijeme provedeno s djetetom u glazbenim aktivnostima jer je Mann-Whitney testom dobivena empirijska razina signifikantnosti $\mathrm{p}=0,053>5 \%$, no može se reći da je utjecaj zaposlenosti roditelja na vrijeme provedeno s djetetom u glazbenim aktivnostima statistički značajan pri razini signifikantnosti od $10 \%$ ( $\mathrm{p}=0,053<10 \%)$ i to na način da obitelji gdje je samo jedan roditelj zaposlen više vremena provode s djecom u glazbenim aktivnostima nego obitelji gdje su oba roditelja zaposlena (Tablica 10).

Tablica 10. Zaposlenost i vrijeme provedeno s djetetom u glazbenim i ostalim (neglazbenim) aktivnostima

\begin{tabular}{|l|c|c|}
\hline & $\begin{array}{c}\text { Prosječno dnevno } \\
\text { vrijeme provedeno s } \\
\text { djetetom u glazbenim } \\
\text { aktivnostima }\end{array}$ & $\begin{array}{c}\text { Prosječno dnevno vrijeme } \\
\text { provedeno s djetetom u } \\
\text { ostalim (neglazbenim) } \\
\text { aktivnostima }\end{array}$ \\
\hline Mann-Whitney U & 521,500 & 579,000 \\
\hline Wilcoxon W & 2006,500 & 2064,000 \\
\hline Z & $-1,938$ & $-1,317$ \\
\hline Asymp. Sig. (2-tailed) &, 053 &, 188 \\
\hline
\end{tabular}

Grouping Variable: Zaposlenost

Ne postoji statistički značajan utjecaj zaposlenosti roditelja na vrijeme provedeno $\mathrm{s}$ djetetom $\mathrm{u}$ ostalim (neglazbenim) aktivnostima $(\mathrm{p}=0,188)$.

Tablica 11. Korelacija između stupnja stručne spreme roditelja i prosječnog vremena kojeg roditelji provode s djecom u glazbenim ili ostalim (neglazbenim) aktivnostima (Sperman's rho)

\begin{tabular}{|c|c|c|}
\hline & & Stručna sprema (prosjek) \\
\hline \multirow{3}{*}{$\begin{array}{l}\text { Prosječno vrijeme dnevno } \\
\text { provedeno s djetetom } \mathrm{u} \\
\text { glazbenim aktivnostima }\end{array}$} & Correlation Coefficient &,- 012 \\
\hline & Sig. (2-tailed) & ,914 \\
\hline & $\mathrm{N}$ & 80 \\
\hline \multirow{3}{*}{$\begin{array}{l}\text { Prosječno vrijeme dnevno } \\
\text { provedeno s djetetom u } \\
\text { ostalim (neglazbenim) } \\
\text { aktivnostima }\end{array}$} & Correlation Coefficient &, 114 \\
\hline & Sig. (2-tailed) & ,313 \\
\hline & $\mathrm{N}$ & 80 \\
\hline
\end{tabular}


U Tablici 11 prikazana je korelacija između stupnja stručne spreme i prosječnog vremena kojeg roditelji provode $\mathrm{s}$ djecom $\mathrm{u}$ glazbenim ili ostalim (neglazbenim) aktivnostima. Za povezanost dvije ordinalne varijable (prosječna stručna sprema oba roditelja na skali 1-9 i vrijeme provedeno s djecom na skali 1-5) koristio se Spearmanov koeficijent korelacije ranga. Spearmanov koeficijent korelacije ranga između stručne spreme oba roditelja i vremena koje provode s djetetom u glazbenim aktivnostima iznosi -0,012 i nije statistički značajan $(p=0,914)$. Spearmanov koeficijent korelacije ranga između stručne spreme oba roditelja i vremena koje provode $\mathrm{s}$ djetetom u ostalim (neglazbenim) aktivnostima iznosi 0,114 i nije statistički značajan ( $p=0,313)$. Na ispitanom uzorku, dakle, ne možemo dokazati da je stručna sprema roditelja povezana s vremenom koje provode s djecom kako u glazbenim tako i u ostalim (neglazbenim) aktivnostima.

\section{Zaključak}

Značajan utjecaj okoline na razvoj djetetovih sposobnosti prepoznaje veliki broj znanstvenika (Manasteriotti, 1982; Dobrota, 2007; Miočić, 2012). Do početka djetetova institucionalnog odgoja presudan utjecaj na razvoj djetetovih urođenih potencijala imaju njegovi roditelji i obitelj općenito. To se u istoj mjeri odnosi i na područje glazbenog (estetskog) odgoja, odnosno na razvoj glazbenih sposobnosti (Dobrota, 2006; Kelley i Sutton-Smith, 1987; Sulentić Begić, 2012).

Istraživanjem se htjelo utvrditi u kojoj mjeri zaposlenost roditelja i njihov stečeni stupanj stručne spreme utječe na količinu vremena koju provode $\mathrm{u}$ glazbenim aktivnostima $\mathrm{s}$ djecom predškolskog uzrasta, $\mathrm{u}$ obiteljskom domu. Rezultati istraživanja ukazuju na to da ne postoji statistički značajan utjecaj zaposlenosti roditelja na vrijeme provedeno $\mathrm{s}$ djetetom u glazbenim aktivnostima. Ipak, pri razini signifikantnosti od $10 \%$ ( $\mathrm{p}=0,053<10 \%)$ utvrđujemo statistički značajan utjecaj zaposlenosti roditelja na vrijeme provedeno s djetetom u glazbenim aktivnostima. Obitelji u kojima je samo jedan roditelj zaposlen više vremena provode s djecom u glazbenim aktivnostima nego obitelji u kojima su oba roditelja zaposlena. Istraživanjem nismo utvrdili ni statistički značajan utjecaj zaposlenosti na vrijeme provedeno u ostalim (neglazbenim) aktivnostima. Hipoteza da zaposlenost roditelja utječe na vrijeme provedeno u glazbenim aktivnostima djelomice je potvrđena, dok se 
hipoteza da zaposlenost roditelja utječe na vrijeme provedeno u ostalim (neglazbenim) aktivnostima odbacuje. Ovdje napomenimo da u uzorku nismo imali niti jedan slučaj gdje su u obitelji oba roditelja nezaposlena.

Rezultati istraživanja upućuju i na to da ne postoji statistički značajan utjecaj stečene stručne spreme roditelja na vrijeme koje provode u glazbenim aktivnostima sa svojom djecom. Jednako tako nije utvrđen ni statistički značajan utjecaj stručne spreme na vrijeme provedeno u ostalim (neglazbenim) aktivnostima s djecom u obiteljskom domu. Oba su rezultata istraživanja potvrdila naše početne hipoteze.

Unatoč tome što je znanost zauzela stav da okolina, prije svega roditelji, u značajnoj mjeri doprinose razvoju glazbenih sposobnosti, neznatan je broj istraživanja koja se bave proučavanjem faktora u obiteljskom domu, a koji bi mogli imati značaj utjecaj na taj razvoj. Stoga su daljnja istraživanja na temu utjecaja roditelja na razvoj glazbenih (i ostalih) sposobnosti djeteta predškolskog uzrasta nasušna potreba, $\mathrm{s}$ ciljem stvaranja poticajnog okruženja za njihov razvoj.

\section{Literatura}

Denac, Olga (2004), »Smisao glazbenog odgoja u cjelokupnom razvoju dječje osobnosti«, Informatologia, 37(3), str. 255-258.

Denac, Olga (2008), »A case study of preschool children's musical interests at home and at school«, Early Childhood Education Journal, 35, str. 439-444. doi: http://dx.doi.org/10.1007/s10643-007-0205-4

Dobrota, Snježana i Ćurković, Gordana (2006), »Glazbene preferencije djece mlađe školske dobi«, Život i škola, 15-16, str. 105-114.

Dobrota, Snježana (2007), »Glazba i dijete«, Zrno, 77, str. 26-31.

Gordon, Edwin (1988), Learning Sequences in Music: Skill, Content, and Patterns: A Music Learning Theory, Chicago: GIA Publications.

Jurak, Alojz (2002), »Roditelji - prvi odgojitelji svoje djece pred izazovom vremena«, Don Bosco danas, 131 (1), str. 4-5.

Kelley, Linda i Sutton-Smith, Brian (1987), »A study of infant musical productivity«, u: Perry, Craig; Perry, Irene Weiss i Draper, Thomas (ur.), Music and child development, New York: Springer-Verlag, str. 35-53. doi: http://dx.doi.org/10.1007/978-1-4613-8698-8_2

Lewinowitz, Lili (1998), »The importance of music in early childhood«, General Music Today, 12(1), str. 4-7. 
Ljubetić, Maja (2007), Biti kompetentan roditelj, Zagreb: Mali profesor.

Manasteriotti, Višnja (1981), Prvi susreti djeteta s muzikom, Zagreb: Školska knjiga.

Manasteriotti, Višnja (1982), Muzički odgoj na početnom stupnju, metodske upute za odgajatelje i nastavnike razredne nastave, Zagreb: Školska knjiga.

Marić, Ljerka i Goran, Ljiljana (2013), Zapjevajmo radosno, Zagreb: Golden marketing-Tehnička knjiga.

Miočić, Magdalena (2012), »Kultura predškolske ustanove u svjetlu glazbenih kompetencija odgojitelja«, Magistra Iadertina, 7 (7), str. 73-85.

Mirković-Radoš, Ksenija (1996), Psihologija muzike, Beograd: Zavod za udžbenike i nastavna sredstva.

Panagiotakou, Christina i Pange, Jenny (2010), »The use of ICT in preschool music education«, Procedia Social and Behavioral Sciences, 2, str. 3055-3059. doi: http://dx.doi.org/10.1016/j.sbspro.2010.03.464

Požgaj, Joža (1988), Metodika nastave glazbene kulture u osnovnoj školi, Zagreb: Školska knjiga.

Slunjski, Edita (2012), Tragovima dječjih stopa, Zagreb: Profil International.

Šulentić Begić, Jasna (2012), »Glazbene sposobnosti u kontekstu utjecaja naslijeđa i okoline $\ll$, Tonovi, 58, str. 23-31.

\title{
PARENTS AND THE CHILDREN'S MUSIC ACTIVITIES IN THE FAMILY HOME
}

\author{
Marijo Krnić, Josipa Kodžoman-Radan
}

We have conducted a research on the impact of the employment status and professional degree of parents to the amount of time they spend with their children in music and other (non-music) activities in their family home. This paper delivers the results. Research was conducted in June 2015 in four kindergartens in the city of Split on a sample of 160 parents of 80 preschool children. Results indicate that there is no statistically significant impact of the parents' employment status and professional degree on the amount of time they spend with their children in music and other (non-music) activities. The impact of parents' employment is statistically significant at the significance level of $10 \%(p=0,053<10 \%)$ in a way that the families with only one employed parent tend to spend more time with children in music activities than families with both employed parents.

Key words: musical abilities, employment status, professional degree, music education, preschool children 